\title{
The transient receptor potential family of ion channels
}

Bernd Nilius and Grzegorz Owsianik*

\begin{abstract}
Summary
The transient receptor potential (TRP) multigene superfamily encodes integral membrane proteins that function as ion channels. Members of this family are conserved in yeast, invertebrates and vertebrates. The TRP family is subdivided into seven subfamilies: TRPC (canonical), TRPV (vanilloid), TRPM (melastatin), TRPP (polycystin), TRPML (mucolipin), TRPA (ankyrin) and TRPN (NOMPC-like); the latter is found only in invertebrates and fish. TRP ion channels are widely expressed in many different tissues and cell types, where they are involved in diverse physiological processes, such as sensation of different stimuli or ion homeostasis. Most TRPs are non-selective cation channels, only few are highly $\mathrm{Ca}^{2+}$ selective, some are even permeable for highly hydrated $\mathrm{Mg}^{2+}$ ions. This channel family shows a variety of gating mechanisms, with modes of activation ranging from ligand binding, voltage and changes in temperature to covalent modifications of nucleophilic residues. Activated TRP channels cause depolarization of the cellular membrane, which in turn activates voltage-dependent ion channels, resulting in a change of intracellular $\mathrm{Ca}^{2+}$ concentration; they serve as gatekeepers for transcellular transport of several cations (such as $\mathrm{Ca}^{2+}$ and $\mathrm{Mg}^{2+}$ ), and are required for the function of intracellular organelles (such as endosomes and lysosomes). Because of their function as intracellular $\mathrm{Ca}^{2+}$ release channels, they have an important regulatory role in cellular organelles. Mutations in several TRP genes have been implicated in diverse pathological states, including neurodegenerative disorders, skeletal dysplasia, kidney disorders and pain, and ongoing research may help find new therapies for treatments of related diseases.
\end{abstract}

${ }^{*}$ Correspondence: grzegorz.owsianik@med.kuleuven.be Department of Molecular Cell Biology, Laboratory of Ion Channel Research, Campus Gasthuisberg, KU Leuven, Herestraat 49, B-3000 Leuven, Belgium

\section{Gene organization and evolutionary history}

Transient receptor potential (TRP) genes were first described in the fruit fly Drosophila melanogaster. Studies in its visual system identified a visually impaired mutant fly that had a transient response to steady light instead of the sustained electro-retinogram recorded in the wild type [1]. This mutant was therefore called transient receptor potential; however, it took about two decades before the trp gene was identified by Montell and Rubin in 1989 [2]. From its structural resemblance to other cation channels and detailed analysis of the permeation properties of the light-induced current in the trp mutant, the product of the trp gene was proposed to be a six-transmembranesegment protein that functions as a $\mathrm{Ca}^{2+}$-permeable cation channel [3]. Currently, more than 100 TRP genes have been identified in various animals (Table 1). Human TRP genes are diverse in length and range between 11.4 and about $911 \mathrm{~kb}$, with the number of exons varying from 11 to 39 . The overall protein sequence homology between subfamily members in the same species is usually about $35 \%$, but for clear duplication pairs (such as TRPC6 and TRPC7, TRPM4 and TRPM5, and TRPV5 and TRPV6) this may reach 50 to $80 \%$. Regulatory elements in promoters of TRP genes have not been identified.

From protein homology, members of the TRP channel family can be seen to fall into seven subfamilies [4]. The number of channels within each subfamily varies across species (Figure 1 and Table 1). The transmembrane segments tend to share the greatest homology within a particular subfamily. The TRPC subfamily ('canonical') comprises closest homologs of Drosophila trp channels. TRPVs ('vanilloid') are named after a founding member vanilloid receptor 1 (now TRPV1). The TRPM subfamily groups homologs of melastatin-1 (now TRPM1). TRPMLs and TRPPs include mucolipins and polycystins, respectively. All members of the TRPA subfamily are nociceptive channels characterized by the presence of about 14 ankyrin repeats. The TRPN subfamily is named after the 'NO-mechano-potential C' (NOMP-C) channel of Caenorhabditis elegans. So far, the only TRPN family member to be identified in vertebrates is from zebrafish [5].

Within the six kingdoms of life, bacteria, protozoa, chromista, plantae, fungi and animalia [6], TRP-related 
Table 1. The TRP channel familya

\begin{tabular}{|c|c|c|c|c|c|c|c|}
\hline & $\begin{array}{c}\text { Drosophila } \\
\text { melanogaster }\end{array}$ & $\begin{array}{l}\text { Caenorhabditis } \\
\text { elegans }^{\mathrm{b}}\end{array}$ & $\begin{array}{c}\text { Ciona } \\
\text { intestinalis }^{\mathrm{b}}\end{array}$ & $\begin{array}{c}\text { Fugu } \\
\text { rubripes }\end{array}$ & $\begin{array}{l}\text { Danio } \\
\text { rerio }^{\text {b }}\end{array}$ & $\begin{array}{c}\text { Mus } \\
\text { musculus }\end{array}$ & $\begin{array}{l}\text { Homo } \\
\text { sapiens }\end{array}$ \\
\hline TRPC & 3 & 3 & 8 & 8 & 8 & 7 & 6 \\
\hline TRPV & 3 & 5 & 2 & 4 & 4 & 6 & 6 \\
\hline TRPM & 1 & 4 & 2 & 6 & 6 & 8 & 8 \\
\hline TRPA & 4 & 2 & 4 & 1 & 2 & 1 & 1 \\
\hline TRPN & 1 & 1 & 1 & - & 1 & - & - \\
\hline TRPML & 4 & 1 & 9 & 2 & 2 & 3 & 3 \\
\hline TRPP & 1 & 1 & 1 & 4 & 4 & 3 & 3 \\
\hline Total & 17 & 17 & 27 & 25 & 27 & 28 & 27 \\
\hline
\end{tabular}

aTRP channels in the fruit fly Drosophila melanogaster, the worm Caenorhabditis elegans, the sea squirt Ciona intestinalis, the puffer fish (Seifuku, Fugu rubripes), the zebrafish (Danio rerio), mouse and human. The numbers correspond to proteins with distinct channel properties within each subfamily [104-106]. For more detailed

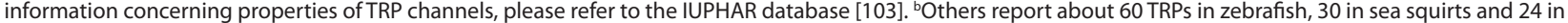
C. elegans.

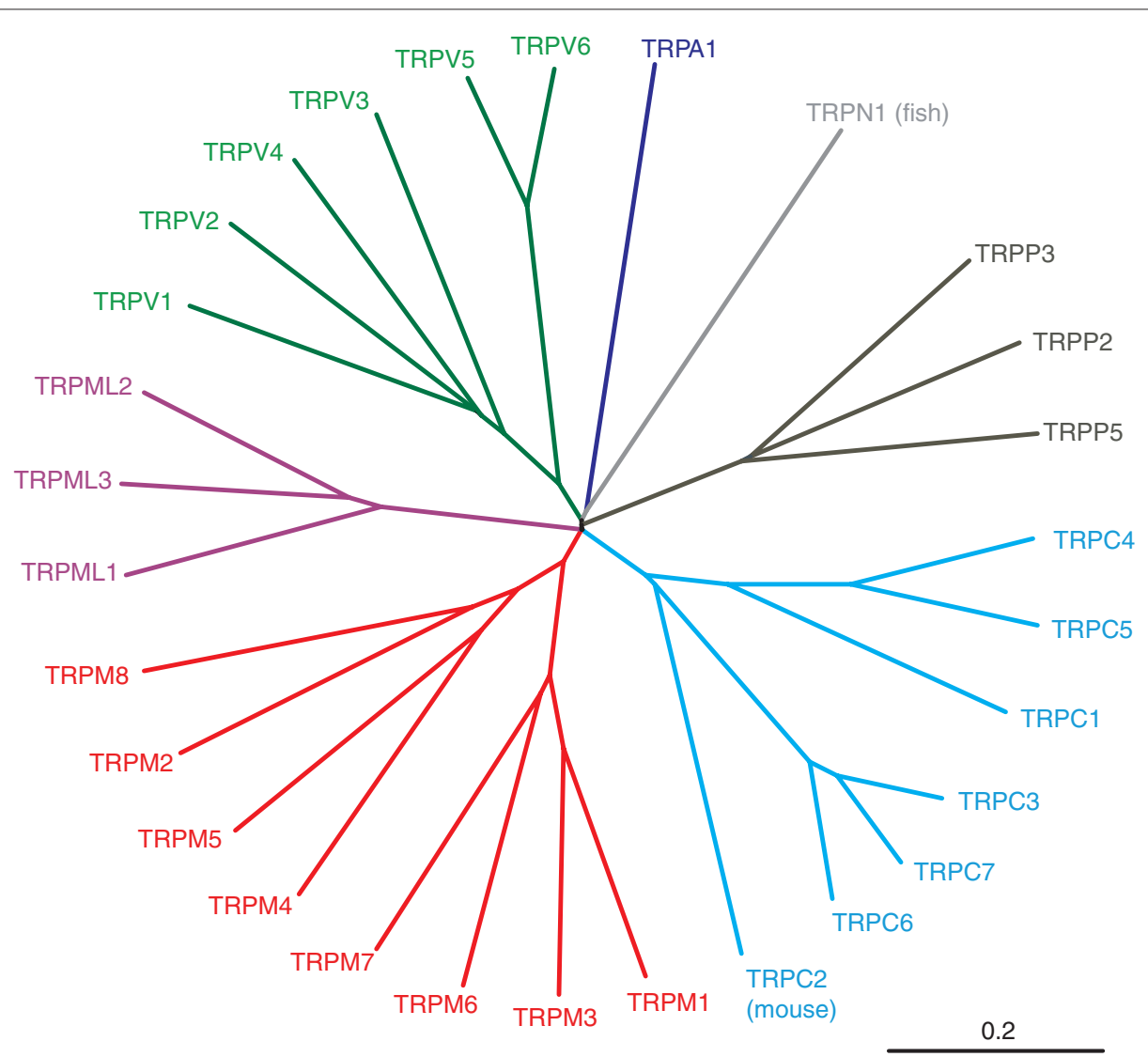

Figure 1. A phylogenetic tree of human TRP channels. Sequence homology analyses show that all TRP channels fall into seven subfamilies that comprise proteins with distinct channel properties. Because TRPC2 is a pseudogene in human and TRPNs are not present in mammals, we used mouse TRPC2 (ENSMUSP00000102562) and fish TRPN1 (ENSDARP00000093955) to show relations between all subfamilies. Protein sequences were aligned using ClustalW2 at the EMBL-EBI server. Phylogenetic distances were calculated using PAM matrix and the unrooted tree was obtained using NJplot [102]. The TRP subfamilies are represented by different colors. The scale bar represents 0.2 substitutions. Ensembl protein IDs for human protein sequences used in the analysis are as follows: TRPM1, ENSP00000380897; TRPM2, ENSP00000381023; TRPM3, ENSP00000350140; TRPM4, ENSP00000252826; TRPM5, ENSP00000387965; TRPM6, ENSP00000354006; TRPM7, ENSP00000320239; TRPM8, ENSP00000323926; TRPV1, ENSP00000174621; TRPV2, ENSP00000342222; TRPV3, ENSP00000301365; TRPV4, ENSP00000261740; TRPV5, ENSP00000265310; TRPV6, ENSP00000352358; TRPC1, ENSP00000273482; TRPC3, ENSP00000368966; TRPC4, ENSP000000369003; TRPC5, ENSP00000262839; TRPC6, ENSP00000340913; TRPC7, ENSP00000426070; TRPML1, ENSP00000264079; TRPML2, ENSP00000359640; TRPML3, ENSP00000304843; TRPP2, ENSP00000237596; TRPP3, ENSP00000325296; TRPP5, ENSP00000290431; TRPA1, ENSP00000262209. 
genes seem to be found only in fungi and animalia. Despite extensive genomic studies, no single TRP-encoding gene has been identified in land plants so far, but the genome of chlorophyte algae seems to contain several types of putative TRP-like genes [7]. In the green alga Ostreococcus tauri, at least one of the putative genes might encode a potential TRP channel involved in a $\mathrm{Ca}^{2+}$ signaling pathway. Therefore, land plants might have lost TRP channels after their divergence from the chlorophyte algae [7].

In fungi, the TRP family is represented by a single member, $\operatorname{Trp} Y 1$ (also known as $Y v c 1$ for yeast vacuolar conductance 1), which encodes a vacuolar membrane protein that functions as a mechano-sensor of vacuolar osmotic pressure in yeast [8-11]. The yeast TRP channel is activated in a $\mathrm{Ca}^{2+}$-dependent manner through stretching of the vacuolar membrane $[12,13]$ as well as by indole and other aromatic compounds [8,9]. The action of aromatic ligands requires the presence of aromatic residues in the sixth transmembrane segment that might be counterparts of those found in several TRP channels of multicellular organisms $[8,9]$. Because TrpY1p shares only partial homology with other known TRPs, it might be considered as one of the ancient mechano- and chemosensors [14,15].

Choanoflagellates are unicellular and colonial organisms considered to be the common ancestor of animals. It has been hypothesized that these colony-forming flagellate eukaryotes developed a $\mathrm{Ca}^{2+}$ signaling system that comprises homologs of various types of animal plasma membrane $\mathrm{Ca}^{2+}$ channels, including the store-operated channel, ligand-operated channels, voltage-operated channels, second messenger-operated channels, and five out of six animal TRP channel families [16]. Thus, it is very likely that these choanoflagellate genes served as ancestors for the evolution of different TRP subfamilies in animals; further expansions within subfamilies may have mainly occurred by gene duplications (Figure 1). During evolution, most vertebrates lost the mechanosensitive TRPN channels but almost doubled the number of TRPs involved in calcium and magnesium homeostasis, thermo- and chemosensing and calcium signaling (TRPCs, TRPVs and TRPMs; Table 1).

\section{Characteristic structural features}

Owing to the shortage of accurate X-ray crystallography data describing the three-dimensional structure of an entire TRP channel, most information concerning TRP domain composition comes from in silico and structure/ function relationship studies. It is thought that most TRPs function as homotetramers. The formation of heteromultimeric channels between members of the same subfamily or different subfamilies has been described in several cases (such as between the TRPCs), and this could potentially create a wide variety of channels; however, it is debatable whether or not these multimeric channels are formed [17]. A typical TRP protein contains six putative transmembrane segments (S1 to S6) with a pore-forming reentrant loop between S5 and S6 $[18,19]$ (Figure 2). Intracellular amino and carboxyl termini are variable in length and consist of a variety of domains [18]. From cryo-electron microscopy data on TRPC3, the large intracellular domain can be seen as a 'nested box' structure: a 'wire frame' outer shell acts as a sensor for activators and modulators, and a globular inner chamber might modulate ion flow [20]. Interestingly, in a few cases the carboxy-terminal tails contain entire enzyme activities. For example, a Nudix hydrolase domain of TRPM2 functions as an ADP-ribose pyrophosphatase [21]. In TRPM6 and TRPM7 an atypical $\alpha$-kinase domain is involved in regulation of channel function [22,23]. Another feature in the amino termini of many TRPs is the presence of ankyrin repeats, 33-residue motifs consisting of pairs of antiparallel $\alpha$-helices connected by $\beta$-hairpin motifs. The number of repeats in the ankyrin repeat domain (ARD) can vary between different TRPs: 3 to 4 in TRPCs, 6 in TRPVs, 14 to 15 in TRPAs and about 29 in TRPNs. Functionally, ARD seems to be connected with tetramerization of the channel and interactions with ligands and protein partners [24]. Currently, the ARD of TRPV channels is the only domain out of the entire TRP superfamily for which high resolution crystallographic data have so far been obtained $[25,26]$.

The presence of other domains and motifs that influence channel functions, such as coiled coils, calmodulinbinding sites, lipid-interaction domains, EF hands or phosphorylation sites, is highly variable and very often not preserved in all members within the same subfamily (for more details see [18]).

\section{Localization and function}

TRPs are expressed in almost every cell type in both excitable and non-excitable tissues (Table 2). TRP channels are present in all cellular membranes, with the exception of the nuclear envelope and mitochondria. Most TRP channels are localized in the plasma membrane, where they have an essential role in the influx and/or transcellular machinery that transports $\mathrm{Ca}^{2+}, \mathrm{Mg}^{2+}$ and trace metal ions, and they modulate the driving force for ion entry. These contributions are essential for several physiological processes, ranging from pure sensory functions (such as pheromone signaling, taste transduction, nociception and temperature sensation) and homeostatic functions (such as $\mathrm{Ca}^{2+}$ and $\mathrm{Mg}^{2+}$ reabsorption and osmoregulation) to many other motile functions, such as muscle contraction and vasomotor control.

The functions of TRP channels at specific locations are often modulated by their associations with accessory 


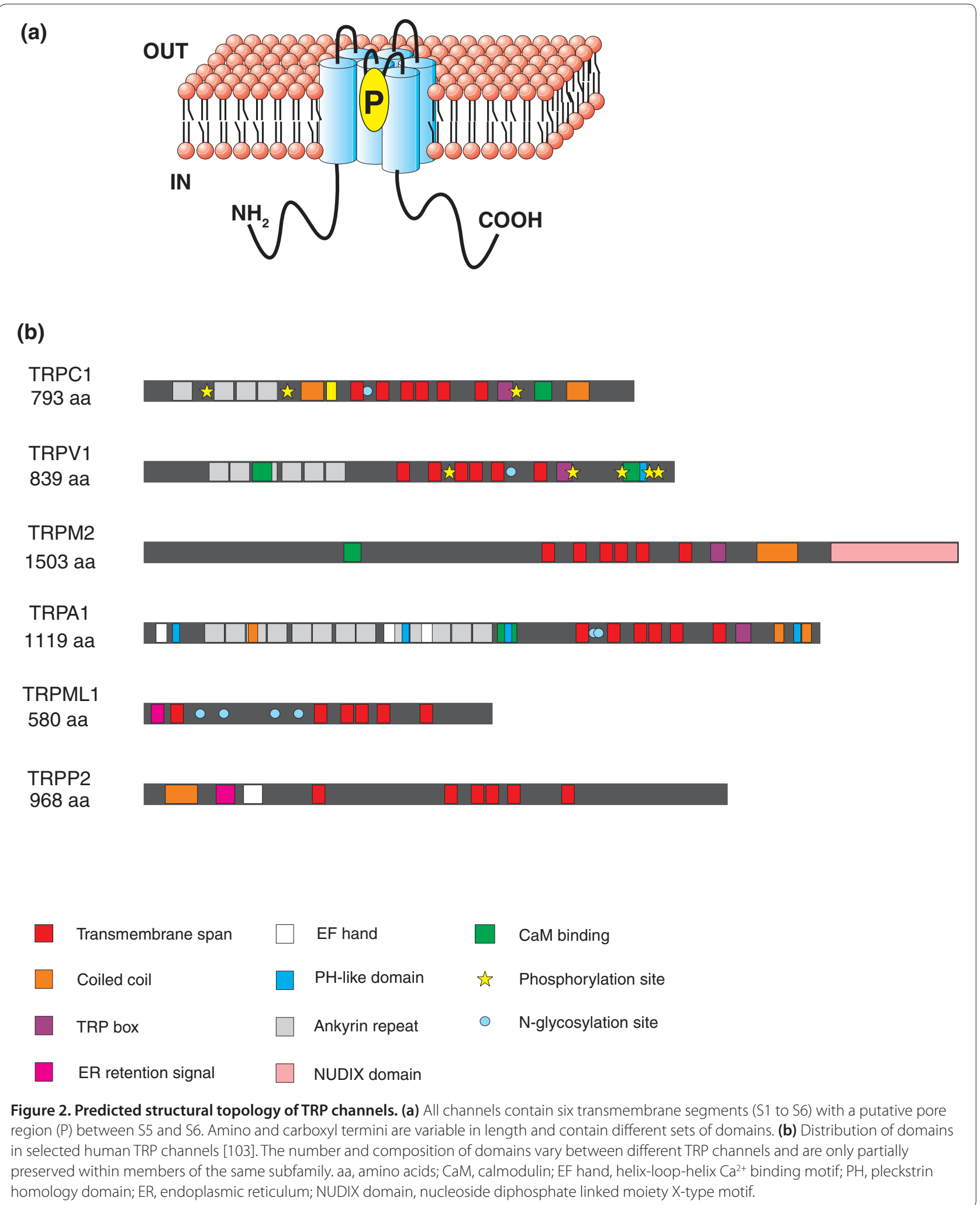

proteins (such as TRPV4 and PACSIN3, a protein kinase $\mathrm{C}$ and casein kinase II substrate in neurons that is involved in synaptic vesicular membrane trafficking and regulation of dynamin-mediated endocytotic processes) and by formation of signaling complexes with various signaling proteins (such as TRPM4 and phospholipase $\mathrm{C}$ 
Table 2. Expression and function of human and mouse TRP channels

\begin{tabular}{|c|c|c|c|}
\hline Channel subunit & Chromosomal location & Cellular expression & Physiological functions \\
\hline \multicolumn{4}{|l|}{ TRPC subfamily } \\
\hline TRPC1 & $\begin{array}{l}\text { Human: } 3 q 22-q 24 ; \\
\text { mouse: } 9 \text { E4 }\end{array}$ & Ubiquitous & $\begin{array}{l}\text { Generation of the excitatory postsynaptic potential in brain; } \\
\text { netrin-1 and brain-derived neurotrophic factor (BDNF)-mediated } \\
\text { growth cone guidance; connections to sleep/wakefulness states, } \\
\text { alertness and appetite; brain development (together with TRPC5); } \\
\text { glutamate signaling in hippocampus; regulation of smooth muscle } \\
\text { contraction pulmonary system; platelet function; skeletal muscle } \\
\text { differentiation; mechano-sensation? }\end{array}$ \\
\hline
\end{tabular}

$\begin{array}{lll}\text { TRPC2 } & \begin{array}{l}\text { Human: 11p15.4-p15.3 } \\ \text { (pseudogene); }\end{array} & \begin{array}{l}\text { Dendritic tips of the vomeronasal } \\ \text { sensory neurons and spermatozoa } \\ \text { (mouse) }\end{array} \\ \text { TRPC3 } & \text { Human: } 4 \mathrm{q} 25-\mathrm{q} 27 ; & \begin{array}{l}\text { Central nervous system (CNS) and } \\ \text { smooth and cardiac muscle cells }\end{array}\end{array}$

TRPC4

TRPC5

TRPC6

TRPC7

TRPV subfamily

TRPV1

$\begin{array}{cl}\text { TRPV2 } & \begin{array}{l}\text { Human: 17p11.2; } \\ \text { mouse: } 11 \mathrm{~B} 2\end{array} \\ & \\ \text { TRPV3 } & \text { Human: 17p13.3; } \\ & \text { mouse: } 11 \mathrm{~B} 4 \\ \text { TRPV4 } & \text { Human: } 12 \mathrm{q} 24.1 ; \\ & \text { mouse: } 5 \mathrm{~F}\end{array}$

TRPV5 Human: 7q35;
Human: 13q13.1-q13.2; mouse: $3 \mathrm{D}$

Human: Xq23-q24; mouse: XF2

Human: 11q21-q22; mouse: 9 A1

Human: 5q31.2; mouse: 13 B2

Human: 17p13.3; mouse: 11 B3
Placenta, adrenal gland, CNS, endothelium, smooth muscle cells, kidney, intestinal cells of Cajal

Brain, especially in fetal brain and very weak expression in other tissues

Smooth muscle cells, lung, brain, placenta, kidney (podocyte foot processes), spleen, ovary and small intestine, neutrophils

Pituitary glands, kidney and CNS (human); heart and lung; weak in CNS and kidney (mouse)

Dorsal root and trigeminal ganglia; spinal and peripheral nerve terminals, brain, skin (cutaneous sensory nerve fibers, mast cells, epidermal keratinocytes, dermal blood vessels, the inner root sheet and the infundibulum of hair follicles, differentiated sebocytes, sweat gland ducts, and the secretory portion of eccrine sweat glands), pancreas, bladder (urothelium, smooth muscle, blood vessels and neurons)

Dorsal root ganglia and CNS neurons, gastro-intestinal tract, spleen, mast cells, smooth, cardiac and skeletal muscle cells

Dorsal root and trigeminal ganglion neurons, brain, keratinocytes, hair follicles, tongue and testis

CNS (large neurons), trigeminal ganglia, heart, liver, kidney, skin (keratinocytes), osteoblasts, blood vessels (endothelium), bladder (urothelium) and testis, cochlea (inner and outer hair cells, marginal cells of the cochlear stria vascularis), kidney (epithelial cells of tubules and glomeruli)

High in kidney; lower in gastro-intestinal tract, pancreas, testis, prostate, placenta, brain and salivary gland
Pheromone detection that regulates sexual and social behaviors, such as gender recognition and male-male aggression (mouse)

BDNF-mediated growth cone guidance (TRPC1-independent); spine formation in brain; $\gamma$-aminobutyric acid signaling in striatum; astrocyte function; moto-control in cerebellum; cerebral vasomotor control; erythropoietin function; functional coupling to orexin receptor

Endothelium-dependent vasorelaxation and regulation of transcellular permeation of the endothelial layer; cell-cell adhesion in endothelium through junctional proteins; hypoxia sensing together with TRPC1

Brain development (together with TRPC1); neurite growth growth cone guidance and morphology; anxiety, fear and reward processing in nucleus accumbens

Vaso-motor regulation; a1 signaling in smooth muscle; smooth muscle proliferation; angiogenesis; endocannabinoid signaling in the brain; promotion of dendrite growth and synapse forming in the developing brain; glomerular filter integrity in the kidney; platelet function; redox sensor; mechano-sensor?

Controls respiratory rhythm activity in pre-Bötzinger complex in the brain

Thermo-sensation (heat); autonomic thermoregulation; nociception; pain management; synaptic plasticity in the brain (long-term depression); endocannabinoid signaling in the brain; food intake regulation; growth cone guidance in the brain; osmosensing in the brain by a particular TRPV1 variant; multiple functions in the gut

Thermo-sensation (noxious heat); nociception; axon outgrowth in spinal motor neurons; critical for phagocytosis in macrophages

Thermo-sensation (moderate heat); nociception; skin integrity, wound healing, hair growth and sebocyte function

Thermo-sensation (moderate heat); mechano-sensation; osmo-sensation; nociception; modulation of cell migration; endothelium vaso-motor control and possible shear stress sensor; mechano-receptor in urothelium (important for voiding control); osteogenesis and osteoclast function; important in human bone and neurodegenerative diseases; control adherens junctions in skin; cochlea

$\mathrm{Ca}^{2+}$ (re)absorption channel in kidney and intestines Continued overleaf 
Table 2. Continued

\begin{tabular}{|c|c|c|c|}
\hline Channel subunit & Chromosomal location & Cellular expression & Physiological functions \\
\hline TRPV6 & $\begin{array}{l}\text { Human: 7q33-q34; } \\
\text { mouse: } 6 \text { B2 }\end{array}$ & $\begin{array}{l}\text { High in gastro-intestinal tract; lower } \\
\text { in kidney, pancreas, testis, prostate, } \\
\text { placenta, brain and salivary gland }\end{array}$ & $\begin{array}{l}\mathrm{Ca}^{2+}(\text { re)absorption channel in intestines and kidney; key player in } \\
\mathrm{Ca}^{2+} / 1,25 \text {-dihydroxyvitamin D3-induced keratinocyte development } \\
\text { in the skin }\end{array}$ \\
\hline \multicolumn{4}{|l|}{ TRPM subfamily } \\
\hline TRPM1 & $\begin{array}{l}\text { Human: } 15 q 13-q 14 ; \\
\text { mouse: } 7 \text { C }\end{array}$ & Skin melanocytes, retinal bipolar ganglia & $\begin{array}{l}\text { Light response in ON bipolar retinal ganglia cells; tumor repressor } \\
\text { in melanoma cells }\end{array}$ \\
\hline TRPM2 & $\begin{array}{l}\text { Human: 21q22.3; mouse: } \\
\text { 10 C1 }\end{array}$ & $\begin{array}{l}\text { Brain, bone marrow, peripheral blood } \\
\text { cells (neutrophils), lung, spleen, eye, } \\
\text { heart and liver }\end{array}$ & $\begin{array}{l}\text { Oxidative and nitrosative stress response; activation of } \\
\text { granulocytes; pancreas insulin release; critical in apoptosis }\end{array}$ \\
\hline TRPM3 & $\begin{array}{l}\text { Human: 9q21.13; mouse: } \\
\text { 19C1 }\end{array}$ & $\begin{array}{l}\text { Primarily in kidney; lower in brain, } \\
\text { sensory neurons, testis, ovary, pancreas } \\
\text { and spinal cord }\end{array}$ & $\begin{array}{l}\text { Steroid hormone (pregnanolon) sensor; possible regulator in } \\
\text { endocrine pancreas, glia cells and cerebellar Purkinje cells }\end{array}$ \\
\hline TRPM4 & $\begin{array}{l}\text { Human: 19q13.32; mouse: } \\
7 \text { B4 }\end{array}$ & $\begin{array}{l}\text { Heart, exo- and endocrine pancreas, } \\
\text { mast cells, smooth muscle, macula } \\
\text { densa, lung and placenta }\end{array}$ & $\begin{array}{l}\text { Mast cell degranulation (histamine release) and migration as a } \\
\text { critical Ca-impermeable cation channel regulating } \mathrm{Ca}^{2+} \text { entry; } \\
\text { catecholamine release from chromaffin cells; vasopressin release } \\
\text { from paraventricular and supraoptic hypothalamic nuclei }\end{array}$ \\
\hline TRPM5 & $\begin{array}{l}\text { Human: 11p15.5; mouse: } \\
\text { 7F5 }\end{array}$ & $\begin{array}{l}\text { Tongue (taste bud cells), lungs, testis, } \\
\text { digestive system, brain, endocrine } \\
\text { pancreas }\end{array}$ & $\begin{array}{l}\text { Taste (sweet, bitter, umami); positive regulator of glucose-induced } \\
\text { insulin release; trigeminal nasal chemoreception }\end{array}$ \\
\hline TRPM6 & $\begin{array}{l}\text { Human: 9q21.13; mouse: } \\
19 \mathrm{~B}\end{array}$ & Kidney, colon and intestine & $\mathrm{Mg}^{2+}$ homeostasis and reabsorption in kidney and intestine \\
\hline TRPM7 & $\begin{array}{l}\text { Human: 15q21; mouse: } \\
2 \text { F2 }\end{array}$ & Ubiquitous & $\begin{array}{l}\mathrm{Mg}^{2+} \text { homeostasis and reabsorption in kidney and intestine; } \\
\text { cell cycle control; gastrulation; development of thymocytes } \\
\text { (thymopoiesis); cell migration; shear stress sensor?; skeletogenesis? }\end{array}$ \\
\hline TRPM8 & $\begin{array}{l}\text { Human: 2q37.1; mouse: } \\
1 \text { C5 }\end{array}$ & $\begin{array}{l}\text { Sensory dorsal root and trigeminal } \\
\text { ganglia neurons, nodose ganglion cells } \\
\text { innervating the upper gut, vascular } \\
\text { smooth muscle cells, liver, gastric } \\
\text { fundus, bladder (urothelium) and } \\
\text { different tissues of the male genital tract; } \\
\text { high in tumors from prostate, breast, } \\
\text { colon, lung and skin }\end{array}$ & Thermo-sensation (cold); sperm motility, acrosome reaction \\
\hline \multicolumn{4}{|l|}{ TRPA1 subfamily } \\
\hline TRPA1 & $\begin{array}{l}\text { Human: 8q13; mouse: } \\
1 \text { A3 }\end{array}$ & $\begin{array}{l}\text { Hair cells, sensory dorsal root and } \\
\text { trigeminal ganglia neurons, fibroblasts }\end{array}$ & $\begin{array}{l}\text { Thermo-sensation (noxious cold); the most versatile chemo-sensor; } \\
\text { mechano-sensation?; nociception; olfactory responses; cold- } \\
\text { induced contraction in colon and bladder }\end{array}$ \\
\hline \multicolumn{4}{|l|}{ TRPML subfamily } \\
\hline TRPML1 & $\begin{array}{l}\text { Human: } 19 p 13.3-13.2 ; \\
\text { mouse: } 8 \text { A1.1 }\end{array}$ & Ubiquitous; intracellular ion channel & $\begin{array}{l}\text { Essential for endocytosis and endosomal/lysosomal function; } \\
\text { regulation of autophagy }\end{array}$ \\
\hline TRPML2 & $\begin{array}{l}\text { Human: 1p22; mouse: } \\
3 \mathrm{H3}\end{array}$ & Ubiquitous; intracellular ion channel & Endosomal/lysosomal function \\
\hline TRPML3 & $\begin{array}{l}\text { Human: 1p22.3; mouse: } \\
3 \mathrm{H} 3\end{array}$ & $\begin{array}{l}\text { Hair cells (stria vascularis, stereocilia); } \\
\text { intracellular ion channel }\end{array}$ & Endosomal/lysosomal function; autophagy; hair cell maturation? \\
\hline \multicolumn{4}{|l|}{ TRPP subfamily } \\
\hline TRPP2 & $\begin{array}{l}\text { Human: 4q22; mouse: } \\
5 \text { E4 }\end{array}$ & $\begin{array}{l}\text { Ubiquitous; mostly in ovary, fetal and } \\
\text { adult kidney, testis, and small intestine } \\
\text { in both motile and primary cilia }\end{array}$ & $\begin{array}{l}\text { Cardiac, skeletal and renal development; integrity of the vessel } \\
\text { wall; negative regulator of endogenous mechano-sensitive } \\
\text { channels; mechano-receptor and flow-sensor in endothelium; } \\
\text { apoptosis }\end{array}$ \\
\hline TRPP3 & $\begin{array}{l}\text { Human: 10q24-q25; } \\
\text { mouse: } 19 \text { D1 }\end{array}$ & $\begin{array}{l}\text { Adult heart, skeletal muscle, brain, } \\
\text { spleen, testis, retina and liver }\end{array}$ & Renal development; part of putative sour sensor \\
\hline TRPP5 & $\begin{array}{l}\text { Human: 5q31; mouse: } \\
18 \text { B3 }\end{array}$ & Testis, brain and kidney & Spermatogenesis? \\
\hline
\end{tabular}

BDNF, brain-derived neurotrophic factor; CNS, central nervous system.

(PLC) isoforms and phosphatidylinositol kinases/phosphatases) $[27,28]$. Currently, the mechanisms of intracellular trafficking of TRP channels and their guidance to the plasma membrane or to intracellular locations are mostly unknown [29].

\section{TRPs and disease}

Several TRP genes are implicated in a wide range of diseases in humans [30,31]. These fall under the umbrella of the 'channelopathies', which are defined as diseases caused by impaired channel functions, resulting from 
either mutations in the encoding gene or an acquired mechanism, such as autoimmunity.

\section{TRPC6}

Mutations in TRPC6 are linked to the human proteinuric kidney disease called focal and segmental glomerulosclerosis (FSGS). FSGS patients show defects in the permeability barrier function in glomeruli, resulting in proteinuria and progressive kidney failure [32-34].

\section{TRPV4}

Mutations in TRPV4 are linked with inherited disorders of bone growth, including brachyolmias and skeletal dysplasias mainly characterized by short trunk, scoliosis and mild short stature [35].

TRPV4 has also been implicated in neurodegenerative disorders, such as scapuloperoneal spinal muscular atrophy (SPSMA) and Charcot-Marie-Tooth disease type 2C (CMT2C, known also as hereditary motor and sensory neuropathy type 2C) [36-39]. SPSMA is described by progressive weakness of scapular and peroneal muscle tissue, bone abnormalities and laryngeal palsy (the paralysis often being accompanied by loss of sensation). CMT2C results in progressive weakness of distal limbs, vocal cords, diaphragm, and intercostal and laryngeal muscles; impaired hearing and vision; some bone abnormalities, such as scoliosis; and bladder urgency and incontinence $[36,37,39]$.

\section{TRPM1}

Melastatin or TRPM1 has been identified as a putative tumor suppressor in melanoma cells [40-42]. Mutations in TRPM1 are linked to autosomal-recessive congenital stationary night blindness (CSNB). CSNB is a heterogeneous group of retinal disorders characterized by nonprogressive impaired night vision and variable decreased visual acuity as a consequence of the loss of function of rod and cone ON bipolar cells in the retina [43-47].

\section{TRPM4}

Mutations resulting in Asn7Lys substitution in the aminoterminal part of the TRPM4 channel cause autosomaldominant progressive familial heart block type 1 (PFHB1), a cardiac bundle branch disorder that affects the electrical conduction of the heart and may progress to a complete heart block. Increased TRPM4 mutant channel density in the plasma membrane, resulting from impaired endocytosis, very likely depolarizes the conduction system and causes the heart block [48].

\section{TRPM6}

The TRPM6 locus is associated with hypomagnesemia with secondary hypocalcemia (HSH/HOMG), an autosomal recessive disorder characterized by low $\mathrm{Mg}^{2+}$ and
$\mathrm{Ca}^{2+}$ levels in serum, resulting from impaired intestinal $\mathrm{Mg}^{2+}$ absorption and renal $\mathrm{Mg}^{2+}$ leak $[49,50]$. TRPM6 has a crucial role in active transcellular $\mathrm{Mg}^{2+}$ uptake at the apical membrane of the brush-border epithelium in intestines. Magnesium overload is also prevented by TRPM6, which is tightly regulated by the intracellular $\mathrm{Mg}^{2+}$ concentration [51].

\section{TRPA 1}

The nociceptive TRPA1 channel is implicated in the etiology of an autosomal dominant familial episodic pain syndrome (FEPS) that is manifested by episodes of upper body pain, triggered by fasting and physical stress. FEPS patients show an enhanced cutaneous flare response with secondary hyperalgesia to punctuate stimuli in the presence of TRPA1 agonists [52].

\section{TRPML1}

Mucolipidosis type IV (MLIV) is caused by mutations in TRPML1. MLIV, an autosomal-recessive neurodegenerative lysosomal storage disorder is linked with psychomotor retardation, ophthalmologic abnormalities, failure of corpus callosum development, blood iron deficiency and achlorhydria [53]. TRPML1 is a calcium and iron permeable intracellular channel in lysosomes and, therefore, possible pathological mechanisms might include block of the endocytotic pathway at the late endosomelysosome level, a defect in autophagy of endocytosed materials and impaired iron transport [54,55].

\section{TRPP2}

Polycystic kidney disease (PKD), the most common inherited form of kidney failure, is associated with a mutation in TRPP2 (known also as polycystin 2). PKD is characterized by the development of large epitheliallined cysts that are filled with fluid and can occupy much of the mass of the abnormally enlarged kidneys, thereby compressing and destroying normal renal tissue and impairing kidney function [56].

\section{Mechanism}

The activity of TRP channels is regulated by a variety of mechanisms. In general, these processes require the whole complement of post-transcriptional modifications, including G-protein-coupled receptor-related mechanisms, (de)phosphorylation and ubiquitination. Some more general mechanisms of TRP channel gating and their relevance to sensory modulation are discussed below.

\section{Membrane voltage}

A significant number of TRP channels, mostly involved in sensory perception, have intrinsic voltage dependence [57-60]. The voltage-dependent activation of TRPs is sensitive to other triggers, such as the presence of ligands 
or changes in temperature that can alter the midpoint of the activation by several hundreds of millivolts $[59,61]$. Similar to voltage-gated potassium channels, the molecular counterparts involved in voltage sensing are probably positively charged lysine and arginine residues in transmembrane segment S4 and the S4-S5 linker [61]. For a recent review on voltage sensing and its relevance to the gating of TRP channels in response to thermal and chemical stimuli, see [62].

\section{Membrane phospholipids}

Several studies report a direct effect of membrane phospholipids in the regulation of TRP channel activity (for example, of TRPA1 and TRPV1) [63-65]. In particular, many TRPs are highly sensitive to phosphatidylinositol 4,5-bisphosphate $\left(\operatorname{Ptd} \operatorname{Ins}(4,5) \mathrm{P}_{2}\right)$, the most abundant acidic phospholipid in the plasma membrane. The plasma membrane level of $\operatorname{PtdIns}(4,5) \mathrm{P}_{2}$ can change rapidly because of the action of different PLC isoforms and phosphatidylinositol kinases/phosphatases, resulting in modulation of TRP channel activity [66-68]. Many membrane-associated enzymes are also sensitive to changes in membrane PtdIns $(4,5) \mathrm{P}_{2}$ levels and, therefore, directly or indirectly can affect TRP channel function. For example, the membrane protein Pirt, which is required for the stimulatory effect of $\operatorname{PtdIns}(4,5) \mathrm{P}_{2}$ on TRPV1 activity, interacts with both phosphoinositides and TRPV1 [64]. Cell-specific variations in the level of such regulatory proteins might explain at least some of the discrepancies relating to the effects of $\operatorname{PtdIns}(4,5) \mathrm{P}_{2}$ on the TRP channel activity [29].

Another PtdIns $(4,5) \mathrm{P}_{2}$-related mechanism has been proposed for the cold- and menthol-sensitive TRPM8 and the $\mathrm{Ca}^{2+}$-activated taste-transducing TRPM5 channels. An increased intracellular $\mathrm{Ca}^{2+}$ concentration leads to activation of $\mathrm{Ca}^{2+}$-dependent PLC (such as $\mathrm{PLC}_{\delta 1}$ ), resulting in depletion of cellular PtdIns $(4,5) \mathrm{P}_{2}$ and a subsequent channel decay $[69,70]$. This $\operatorname{Ptd} \operatorname{Ins}(4,5) \mathrm{P}_{2}$ depletion does not lead to complete channel inactivation, but rather shifts the voltage dependence of channel activity to more positive potentials and reduces the channel sensitivity (desensitization) to ligands such as menthol (TRPM8) or $\mathrm{Ca}^{2+}$ (TRPM5) [71]. Endolysosome-localized TRPML channels interact directly with phosphatidylinositol 3,5-bisphosphate, an endolysosome-specific phosphoinositide, resulting in highly specific and potent activation of these channels [72].

\section{Phosphorylation}

Activation of PLC not only results in breakdown of $\operatorname{PtdIns}(4,5) \mathrm{P}_{2}$ but also in the activation of protein kinase C (PKC). PKC-dependent phosphorylation might be a direct activatory mechanism or might sensitize the channel for other stimuli (for example, it sensitizes
TRPV1 to heat or capsaicin) [73,74]. However, PKC might downregulate the channel function: activation of PKC initiates the dephosphorylation of TRPM8 and subsequent inactivation of this channel [75]. The identities of the kinases that mediate phosphorylation of TRPM8 and the phosphorylation site in TRPM8 are still unknown.

An additional pathway for the regulation of TRP channel activity following receptor stimulation is through protein kinase A (PKA). Activation of PKA by prostaglandin E2 stimulation potentiates TRPV1 responses and counteracts channel desensitization [74]. The PKAdependent modulation of TRPV1 requires anchoring of PKA to the channel through the A-kinase anchoring protein AKAP150 and phosphorylation of a single amino-terminal serine residue [74,76]. In TRPM8, PKA activation leads to desensitization of the channel activity by an as yet unknown mechanism. Both PKA- and PKCdependent pathways have opposite effects on modulation of the heat-activated TRPV1 and the cold-activated TRPM8 [77].

\section{Ligands}

Most TRP channel activities are modulated by a large number of exogenous and endogenous ligands. In particular, temperature-sensitive TRPs seem to be preferred targets for plant-derived chemicals. The classic example is heat-sensitive TRPV1, which is activated by structurally unrelated botanical compounds such as capsaicin (the pungent extract of hot peppers [78]), resiniferatoxin (an active compound from the cactus Euphorbia resinifera [79]), piperine (the pungent component in black pepper [80]) and camphor (the waxy substance with penetrating odor extracted from Cinnamomum camphora [81], which also activates TRPV3 [82]). Other examples include TRPM8, a cold receptor directly activated by menthol (derived from the mint plant Mentha piperita) and eucalyptol (derived from the tree Eucalyptus globulus), $[83,84]$, and TRPV4, which is activated by bisandrographolide (derived from the plant Andrographis paniculata [85]). Thus, inherent thermal sensation linked to application of certain chemical compounds (chemesthesis) is related to activation of a single channel that can respond to both thermal and chemical stimuli (such as 'hot' chili pepper or 'cool' mint).

In addition to natural plant-derived compounds, TRP channels respond to a wide range of synthetic ligands, many of which are important pharmacological tools that can be used to modulate channel functions. Some can activate more than one TRP channel (for example, 2-aminoethyl diphenylborinate activates TRPV1, TRPV2 and TRPV3 [86,87] and icilin activates TRPM8 and TRPA1 $[83,88])$, whereas some are relatively highly selective for a particular TRP channel (such as olvanil for 
TRPV1 [89] and $4 \alpha$-phorbol-12,13-didecanoate (4 $\alpha$-PDD), lumiphorbols, phorbol-hexonates and GSK 1016790A for TRPV4 [90-92]).

Several TRP channels are receptors for endogenous compounds. TRPCs respond to diacyl glycerol, a lipid product derived from $\operatorname{PtdIns}(4,5) \mathrm{P}_{2}$ breakdown catalyzed by PLC after a G-protein- or tyrosine-kinase-coupled receptor-dependent activation [93]. Arachidonic-acidrelated compounds are involved in gating TRPV1 (arachidonoyl ethanolamide, 12,15-(S)-hydroperoxyeicosatetraenoic acid and leukotriene $\mathrm{B}_{4}$ [94]) and TRPV4 (5,6'-epoxieicosatrienoic acid [95]), and sphingosine, a primary part of sphingolipids, activates TRPM3 [96]. However, the mechanisms of these gating behaviors of TRP channels are currently unknown.

\section{Frontiers}

The discovery of TRP channels has revolutionized our understanding of many sensory and general physiological processes. TRPs generally act in concert with other ion channels and proteins. Given that, in many cases, these mechanisms are evolutionarily conserved from invertebrates to humans, it is not surprising that inherited impairments of TRP channel functions lead to disease. In addition, changes in channel expression levels or channel sensitization or desensitization, resulting in exaggerated or diminished responses to various pathological stimuli, can also contribute to pathophysiology of TRP-related diseases. Various endogenous agents released during early disease stages can also influence TRP channel functions and lead to inflammation and the progression of the disease (for example, release of leukotriene $\mathrm{B}_{4}$ leads to TRPV1 activation). These findings highlight TRP channels as important pharmacological targets. Several TRPV1 antagonists function as analgesic agents for the treatment of chronic pathological pain [97]. The classic natural pungent TRPV1 agonist, capsaicin, has been reported as a possible relief agent for some patients with tonic neuropathic pain [98]. Several lines of evidence suggest that blocking TRPC6 function might be clinically beneficial for FSGS patients [99]. Preliminary results demonstrate that the commonly used immunosuppressive agent FK-506 can inhibit TRPC6 activity in vivo and might be a possible treatment for idiopathic FSGS [100]. Another example is a small molecule antagonist of TRPV4, HC-067047, which may provide promising means for the treatment of bladder dysfunction [101]. Therefore, further understanding of the (patho) physiological roles and activation mechanisms of these channels may provide novel insights into the etiology and possible treatments of many TRP-related diseases.

Acknowledgements

We thank all members of our laboratory for helpful comments and

discussions. This work was supported by grants from Interuniversity
Attraction Poles Programme (Belgian State- Belgian Science Policy, P6/28), the Research Foundation-Flanders (G.0172.03 and G.0565.07), the Research Council of the KU Leuven (GOA 2004/07) and the Flemish Government (Excellentiefinanciering, EF/95/010).

Published: 17 March 2011

\section{References}

1. Cosens DJ, Manning A: Abnormal electroretinogram from a Drosophila mutant. Nature 1969, 224:285-287

2. Montell C, Rubin GM: Molecular characterization of the Drosophila trp locus: a putative integral membrane protein required for phototransduction. Neuron 1989, 2:1313-1323.

3. Hardie RC, Minke B: The trp gene is essential for a light-activated $\mathrm{Ca}^{2+}$ channel in Drosophila photoreceptors. Neuron 1992, 8:643-651.

4. Wu LJ, Sweet TB, Clapham DE: International Union of Basic and Clinical Pharmacology. LXXVI. Current progress in the mammalian TRP ion channel family. Pharmacol Rev 2010, 62:381-404.

5. Sidi S, Friedrich RW, Nicolson T: NompC TRP channel required for vertebrate sensory hair cell mechanotransduction. Science 2003, 301:96-99.

6. Cavalier-Smith T: Only six kingdoms of life. Proc Bio/ Sci 2004, 271:1251-1262

7. Wheeler $\mathrm{GL}$, Brownlee $\mathrm{C}: \mathrm{Ca}(2+)$ signalling in plants and green algae changing channels. Trends Plant Sci 2008, 13:506-514.

8. Zhou X, Su Z, Anishkin A, Haynes WJ, Friske EM, Loukin SH, Kung C, Saimi Y: Yeast screens show aromatic residues at the end of the sixth helix anchor transient receptor potential channel gate. Proc Natl Acad Sci U S A 2007, 104:15555-15559.

9. Su Z, Zhou X, Haynes WJ, Loukin SH, Anishkin A, Saimi Y, Kung C: Yeast gainof-function mutations reveal structure-function relationships conserved among different subfamilies of transient receptor potential channels. Proc Natl Acad Sci U S A 2007, 104:19607-19612.

10. Myers BR, Bohlen CJ, Julius D: A yeast genetic screen reveals a critical role for the pore helix domain in TRP channel gating. Neuron 2008, 58:362-373.

11. Chang Y, Schlenstedt G, Flockerzi V, Beck A: Properties of the intracellular transient receptor potential (TRP) channel in yeast, Yvc1. FEBS Lett 2010, 584:2028-2032.

12. Su Z, Zhou X, Loukin SH, Haynes WJ, Saimi Y, Kung C: The use of yeast to understand TRP-channel mechanosensitivity. Pflugers Arch 2009, 458:861-867.

13. Su Z, Zhou X, Loukin SH, Saimi Y, Kung C: Mechanical force and cytoplasmic $\mathrm{Ca}(2+)$ activate yeast TRPY1 in parallel. J Membr Biol 2009, 227:141-150

14. Palmer CP, Zhou XL, Lin J, Loukin SH, Kung C, Saimi Y: A TRP homolog in Saccharomyces cerevisiae forms an intracellular $\mathrm{Ca}^{2+}$ - permeable channel in the yeast vacuolar membrane. Proc Natl Acad Sci U S A 2001, 98:7801-7805

15. Denis V, Cyert MS: Internal $\mathrm{Ca}^{2+}$ release in yeast is triggered by hypertonic shock and mediated by a TRP channel homologue. J Cell Biol 2002, 156:29-34.

16. Cai X: Unicellular Ca2+ signaling 'toolkit' at the origin of metazoa. Mol Biol Evol 2008, 25:1357-1361.

17. Hofmann T, Schaefer M, Schultz G, Gudermann T: Subunit composition of mammalian transient receptor potential channels in living cells. Proc Natl Acad Sci U S A 2002, 99:7461-7466.

18. Owsianik G, D'Hoedt D, Voets T, Nilius B: Structure-function relationship of the TRP channel superfamily. Rev Physiol Biochem Pharmacol 2006, 156:61-90

19. Gaudet R: TRP channels entering the structural era. J Physio/ 2008, 586:3565-3575.

20. Mio K, Ogura T, Kiyonaka S, Hiroaki Y, Tanimura Y, Fujiyoshi Y, Mori Y, Sato C: The TRPC3 channel has a large internal chamber surrounded by signal sensing antennas. J Mol Bio/ 2007, 367:373-383.

21. Perraud AL, Fleig A, Dunn CA, Bagley LA, Launay P, Schmitz C, Stokes AJ, Zhu Q, Bessman MJ, Penner R, Kinet JP, Scharenberg AM: ADP-ribose gating of the calcium-permeable LTRPC2 channel revealed by Nudix motif homology. Nature 2001, 411:595-599.

22. Runnels LW, Yue L, Clapham DE: TRP-PLIK, a bifunctional protein with kinase and ion channel activities. Science 2001, 291:1043-1047.

23. Nadler MJ, Hermosura MC, Inabe K, Perraud AL, Zhu Q, Stokes AJ, Kurosaki T, Kinet JP, Penner R, Scharenberg AM, Fleig A: LTRPC7 is a Mg.ATP-regulated divalent cation channel required for cell viability. Nature 2001, 411:590-595

24. Gaudet R: A primer on ankyrin repeat function in TRP channels and 
beyond. Mol Biosyst 2008, 4:372-379

25. Jin X, Touhey J, Gaudet R: Structure of the N-terminal ankyrin repeat domain of the TRPV2 ion channel. J Biol Chem 2006, 281:25006-25010

26. Gaudet R: Divide and conquer: high resolution structural information on TRP channel fragments. J Gen Physiol 2009, 133:231-237.

27. Cuajungco MP, Grimm C, Oshima K, D'Hoedt D, Nilius B, Mensenkamp AR, Bindels RJ, Plomann M, Heller S: PACSINs bind to the TRPV4 cation channel. PACSIN 3 modulates the subcellular localization of TRPV4. J Biol Chem 2006, 281:18753-18762

28. D'Hoedt D, Owsianik G, Prenen J, Cuajungco MP, Grimm C, Heller S, Voets T, Nilius B: Stimulus-specific modulation of the cation channel TRPV4 by PACSIN 3. J Biol Chem 2008, 283:6272-6280

29. Gees M, Colsoul B, Nilius B: The role of transient receptor potential cation channels in Ca2+ signaling. Cold Spring Harb Perspect Biol 2010, 2:a003962.

30. Nilius B, Owsianik G, Voets T, Peters JA: Transient receptor potential cation channels in disease. Physiol Rev 2007, 87:165-217.

31. Nilius B, Owsianik G: Transient receptor potential channelopathies. Pflugers Arch 2010, 460:437-450

32. Kriz W: TRPC6 - a new podocyte gene involved in focal segmental glomerulosclerosis. Trends Mol Med 2005, 11:527-530

33. Reiser J, Polu KR, Moller CC, Kenlan P, Altintas MM, Wei C, Faul C, Herbert S, Villegas I, Avila-Casado C, McGee M, Sugimoto H, Brown D, Kalluri R, Mundel P, Smith PL, Clapham DE, Pollak MR: TRPC6 is a glomerular slit diaphragmassociated channel required for normal renal function. Nat Genet 2005, 37:739-744

34. Winn MP, Conlon PJ, Lynn KL, Farrington MK, Creazzo T, Hawkins AF, Daskalakis N, Kwan SY, Eversviller S, Burchette JL, Pericak-Vance MA, Howell DN, Vance JM, Rosenberg PB: A mutation in the TRPC6 Cation channel causes familial focal segmental glomerulosclerosis. Science 2005, 308:1801-1804.

35. Rock MJ, Prenen J, Funari VA, Funari TL, Merriman B, Nelson SF, Lachman RS, Wilcox WR, Reyno S, Quadrelli R, Vaglio A, Owsianik G, Janssens A, Voets T, Ikegawa S, Nagai T, Rimoin DL, Nilius B, Cohn DH: Gain-of-function mutations in TRPV4 cause autosomal dominant brachyolmia. Nat Genet 2008, 40:999-1003

36. Deng HX, Klein CJ, Yan J, Shi Y, Wu Y, Fecto F, Yau HJ, Yang Y, Zhai H, Siddique N, Hedley-Whyte ET, Delong R, Martina M, Dyck PJ, Siddique T: Scapuloperoneal spinal muscular atrophy and CMT2C are allelic disorders caused by alterations in TRPV4. Nat Genet 2010, 42:165-169.

37. Landoure G, Zdebik AA, Martinez TL, Burnett BG, Stanescu HC, Inada H, Shi Y Taye AA, Kong L, Munns CH, Choo SS, Phelps CB, Paudel R, Houlden H, Ludlow CL, Caterina MJ, Gaudet R, Kleta R, Fischbeck KH, Sumner CJ: Mutations in TRPV4 cause Charcot-Marie-Tooth disease type 2C. Nat Genet 2010, 42:170-174

38. Nilius B, Owsianik G: Channelopathies converge on TRPV4. Nat Genet 2010, 42:98-100.

39. Auer-Grumbach M, Olschewski A, Papic L, Kremer H, McEntagart ME, Uhrig S, Fischer C, Frohlich E, Balint Z, Tang B, Strohmaier H, Lochmüller H, SchlotterWeigel B, Senderek J, Krebs A, Dick KJ, Petty R, Longman C, Anderson NE, Padberg GW, Schelhaas HJ, van Ravenswaaij-Arts CM, Pieber TR, Crosby AH, Guelly C: Alterations in the ankyrin domain of TRPV4 cause congenital distal SMA, scapuloperoneal SMA and HMSN2C. Nat Genet 2010, 42:160-164.

40. Miller AJ, Du J, Rowan S, Hershey CL, Widlund HR, Fisher DE: Transcriptional regulation of the melanoma prognostic marker melastatin (TRPM1) by MITF in melanocytes and melanoma. Cancer Res 2004, 64:509-516,

41. Duncan LM, Deeds J, Cronin FE, Donovan M, Sober AJ, Kauffman M, McCarthy $\mathrm{JJ}$ : Melastatin expression and prognosis in cutaneous malignant melanoma. J Clin Oncol 2001, 19:568-576.

42. Duncan LM, Deeds J, Hunter J, Shao J, Holmgren LM, Woolf EA, Tepper RI, Shyjan AW: Down-regulation of the novel gene melastatin correlates with potential for melanoma metastasis. Cancer Res 1998, 58:1515-1520.

43. Audo I, Kohl S, Leroy BP, Munier FL, Guillonneau X, Mohand-Said S, Bujakowska K, Nandrot EF, Lorenz B, Preising M, Kellner U, Renner AB, Bernd A, Antonio A, Moskova-Doumanova V, Lancelot ME, Poloschek CM, Drumare I, Defoort-Dhellemmes S, Wissinger B, Léveillard T, Hamel CP, Schorderet DF, De Baere E, Berger W, Jacobson SG, Zrenner E, Sahel JA, Bhattacharya SS, Zeitz C: TRPM1 is mutated in patients with autosomal-recessive complete congenital stationary night blindness. Am J Hum Genet 2009, 85:720-729.

44. Bellone RR, Brooks SA, Sandmeyer L, Murphy BA, Forsyth G, Archer S, Bailey E, Grahn B: Differential gene expression of TRPM1, the potential cause of congenital stationary night blindness and coat spotting patterns (LP) in the Appaloosa horse (Equus caballus). Genetics 2008, 179:1861-1870.

45. Nakajima Y, Moriyama M, Hattori M, Minato N, Nakanishi S: Isolation of ON bipolar cell genes via hrGFP-coupled cell enrichment using the mGluR6 promoter. J Biochem 2009, 145:811-818.

46. van Genderen MM, Bijveld MM, Claassen YB, Florijn RJ, Pearring JN, Meire FM, McCall MA, Riemslag FC, Gregg RG, Bergen AA, Kamermans M: Mutations in TRPM1 are a common cause of complete congenital stationary night blindness. Am J Hum Genet 2009, 85:730-736.

47. Li Z, Sergouniotis PI, Michaelides M, Mackay DS, Wright GA, Devery S, Moore AT, Holder GE, Robson AG, Webster AR: Recessive mutations of the gene TRPM1 abrogate ON bipolar cell function and cause complete congenital stationary night blindness in humans. Am J Hum Genet 2009, 85:711-719.

48. Kruse M, Schulze-Bahr E, Corfield V, Beckmann A, Stallmeyer B, Kurtbay G, Ohmert I, Brink P, Pongs O: Impaired endocytosis of the ion channel TRPM4 is associated with human progressive familial heart block type I. J Clin Invest 2009, 119:2737-2744

49. Schlingmann KP, Sassen MC, Weber S, Pechmann U, Kusch K, Pelken L, Lotan D, Syrrou M, Prebble JJ, Cole DE, Metzger DL, Rahman S, Tajima T, Shu SG Waldegger S, Seyberth HW, Konrad M: Novel TRPM6 mutations in 21 families with primary hypomagnesemia and secondary hypocalcemia. J Am Soc Nephrol 2005, 16:3061-3069.

50. Walder RY, Landau D, Meyer P, Shalev H, Tsolia M, Borochowitz Z, Boettger MB, Beck GE, Englehardt RK, Carmi R, Sheffield VC: Mutation of TRPM6 causes familial hypomagnesemia with secondary hypocalcemia. Nat Genet 2002, 31:171-174.

51. Voets T, Nilius B, Hoefs $S$, van der Kemp AW, Droogmans $G$, Bindels RJ, Hoenderop JG: TRPM6 forms the Mg2+ influx channel involved in intestinal and renal Mg2+ absorption. J Biol Chem 2004, 279:19-25.

52. Kremeyer B, Lopera F, Cox JJ, Momin A, Rugiero F, Marsh S, Woods CG, Jones NG, Paterson KJ, Fricker FR, Villegas A, Acosta N, Pineda-Trujillo NG, Ramírez JD, Zea J, Burley MW, Bedoya G, Bennett DL, Wood JN, Ruiz-Linares A: A gainof-function mutation in TRPA1 causes familial episodic pain syndrome. Neuron 2010, 66:671-680.

53. Bach G: Mucolipin 1: endocytosis and cation channel-a review. Pflugers Arch 2005, 451:313-317.

54. Cheng X, Shen D, Samie M, Xu H: Mucolipins: intracellular TRPML1-3 channels. FEBS Lett 2010, 584:2013-2021.

55. Puertollano R, Kiselyov K: TRPMLs: in sickness and in health. Am J Physiol Renal Physiol 2009, 296:F1245-1254.

56. Grantham JJ: Polycystic kidney disease: hereditary and acquired. Adv Intern Med 1993, 38:409-420.

57. Nilius B, Prenen J, Droogmans G, Voets T, Vennekens R, Freichel M, Wissenbach U, Flockerzi V: Voltage dependence of the Ca2+-activated cation channel TRPM4. J Biol Chem 2003, 278:30813-30820.

58. Nilius B, Talavera K, Owsianik G, Prenen J, Droogmans G, Voets T: Gating of TRP channels: a voltage connection? J Physiol (Lond) 2005, 567:33-44.

59. Voets T, Droogmans G, Wissenbach U, Janssens A, Flockerzi V, Nilius B: The principle of temperature-dependent gating in cold- and heat-sensitive TRP channels. Nature 2004, 430:748-754

60. Voets T, Talavera K, Owsianik G, Nilius B: Sensing with TRP channels. Nat Biol Chem 2005, 1:85-92.

61. Voets T, Owsianik G, Janssens A, Talavera K, Nilius B: TRPM8 voltage sensor mutants reveal a mechanism for integrating thermal and chemical stimuli. Nat Chem Biol 2007 3:174-182

62. Talavera K, Yasumatsu K, Yoshida R, Margolskee RF, Voets T, Ninomiya Y, Nilius $B$ : The taste transduction channel TRPM 5 is a locus for bitter-sweet taste interactions. FASEB J 2008, 22:1343-1355.

63. Karashima Y, Prenen J, Meseguer V, Owsianik G, Voets T, Nilius B: Modulation of the transient receptor potential channel TRPA 1 by phosphatidylinositol 4,5-biphosphate manipulators. Pflugers Arch 2008, 457:77-89.

64. Kim AY, Tang Z, Liu Q, Patel KN, Maag D, Geng Y, Dong X: Pirt, a phosphoinositide-binding protein, functions as a regulatory subunit of TRPV1. Cell 2008, 133:475-485

65. Stein AT, Ufret-Vincenty CA, Hua L, Santana LF, Gordon SE: Phosphoinositide 3-kinase binds to TRPV1 and mediates NGF-stimulated TRPV1 trafficking to the plasma membrane. J Gen Physio/ 2006, 128:509-522.

66. Nilius B, Owsianik G, Voets T: Transient receptor potential channels meet phosphoinositides. EMBO J 2008, 27:2809-2816

67. Rohacs T, Nilius B: Regulation of transient receptor potential (trp) channels by phosphoinositides. Pflugers Arch 2007, 455:157-168. 
68. Voets T, Nilius B: Modulation of TRPs by PIPs. J Physio/ 2007, 582:939-944.

69. Liu B, Qin F: Functional control of cold- and menthol-sensitive TRPM8 ion channels by phosphatidylinositol 4,5-bisphosphate. J Neurosci 2005, 25:1674-1681.

70. Rohacs T, Lopes CM, Michailidis I, Logothetis DE: PI(4,5)P(2) regulates the activation and desensitization of TRPM8 channels through the TRP domain. Nat Neurosci 2005, 8:626-634

71. Nilius B, Mahieu F, Prenen J, Janssens A, Owsianik G, Vennekens R, Voets T: The Ca2+-activated cation channel TRPM4 is regulated by phosphatidylinositol 4,5-biphosphate. EMBO J 2006, 25:467-478.

72. Dong XP, Shen D, Wang X, Dawson T, Li X, Zhang Q, Cheng X, Zhang Y, Weisman LS, Delling M, Xu H: PI(3,5)P(2) controls membrane traffic by direct activation of mucolipin Ca release channels in the endolysosome. Nat Commun 2010, 1:pii38.

73. Premkumar LS, Ahern GP: Induction of vanilloid receptor channel activity by protein kinase C. Nature 2000, 408:985-990.

74. Bhave G, Hu HJ, Glauner KS, Zhu W, Wang H, Brasier DJ, Oxford GS, Gereau RWt: Protein kinase $C$ phosphorylation sensitizes but does not activate the capsaicin receptor transient receptor potential vanilloid 1 (TRPV1). Proc Natl Acad Sci U S A 2003, 100:12480-12485.

75. Premkumar LS, Raisinghani M, Pingle SC, Long C, Pimentel F: Downregulation of transient receptor potential melastatin 8 by protein kinase C-mediated dephosphorylation. J Neurosci 2005, 25:11322-11329.

76. Jeske NA, Diogenes A, Ruparel NB, Fehrenbacher JC, Henry M, Akopian AN, Hargreaves KM: A-kinase anchoring protein mediates TRPV1 thermal hyperalgesia through PKA phosphorylation of TRPV1. Pain 2008, 38:604-616.

77. De Petrocellis L, Starowicz K, Moriello AS, Vivese M, Orlando P, Di Marzo V: Regulation of transient receptor potential channel of melastatin type 8 (TRPM8): effect of CAMP, cannabinoid and endovailloids. Exp Cell Res 2007 313:1911-1920.

78. Caterina MJ, Schumacher MA, Tominaga M, Rosen TA, Levine JD, Julius D: The capsaicin receptor: a heat-activated ion channel in the pain pathway. Nature 1997, 389:816-824.

79. Szallasi A, Szabo T, Biro T, Modarres S, Blumberg PM, Krause JE, Cortright DN, Appendino G: Resiniferatoxin-type phorboid vanilloids display capsaicinlike selectivity at native vanilloid receptors on rat DRG neurons and at the cloned vanilloid receptor VR1. Br J Pharmaco/ 1999, 128:428-434.

80. McNamara FN, Randall A, Gunthorpe MJ: Effects of piperine, the pungent component of black pepper, at the human vanilloid receptor (TRPV1). Br J Pharmacol 2005, 144:781-790.

81. Xu H, Blair NT, Clapham DE: Camphor activates and strongly desensitizes the transient receptor potential vanilloid subtype 1 channel in a vanilloidindependent mechanism. J Neurosci 2005, 25:8924-8937.

82. Moqrich A, Hwang SW, Earley TJ, Petrus MJ, Murray AN, Spencer KS, Andahazy M, Story GM, Patapoutian A: Impaired thermosensation in mice lacking TRPV3, a heat and camphor sensor in the skin. Science 2005, 307:1468-1472

83. McKemy DD, Neuhausser WM, Julius D: Identification of a cold receptor reveals a general role for TRP channels in thermosensation. Nature 2002, 416:52-58.

84. Peier AM, Mogrich A, Hergarden AC, Reeve AJ, Andersson DA, Story GM, Earley TJ, Dragoni I, McIntyre P, Bevan S, Patapoutian A: A TRP channel that senses cold stimuli and menthol. Cell 2002, 108:705-715.

85. Smith PL, Maloney KN, Pothen RG, Clardy J, Clapham DE: Bisandrographolide from Andrographis paniculata activates TRPV4 channels. J Biol Chem 2006, 281:29897-29904.

86. Chung MK, Lee H, Mizuno A, Suzuki M, Caterina MJ: 2-aminoethoxydiphenyl borate activates and sensitizes the heat-gated ion channel TRPV3. J Neurosci 2004, 24:5177-5182.

87. Hu HZ, Gu Q, Wang C, Colton CK, Tang J, Kinoshita-Kawada M, Lee LY, Wood JD, Zhu MX: 2-aminoethoxydiphenyl borate is a common activator of TRPV1, TRPV2, and TRPV3. J Biol Chem 2004, 279:35741-35748.

88. Story GM, Peier AM, Reeve AJ, Eid SR, Mosbacher J, HricikTR, Earley TJ, Hergarden AC, Andersson DA, Hwang SW, Mclntyre P, Jegla T, Bevan S,
Patapoutian A: ANKTM1, a TRP-like channel expressed in nociceptive neurons, is activated by cold temperatures. Cell 2003, 112:819-829.

89. lida T, Moriyama T, Kobata K, Morita A, Murayama N, Hashizume S, Fushiki T, Yazawa S, Watanabe T, Tominaga M: TRPV1 activation and induction of nociceptive response by a non-pungent capsaicin-like compound, capsiate. Neuropharmacology 2003, 44:958-967

90. Watanabe H, Davis JB, Smart D, Jerman JC, Smith GD, Hayes P, Vriens J, Cairns W, Wissenbach U, Prenen J, Flockerzi V, Droogmans G, Benham CD, Nilius B: Activation of TRPV4 channels (hVRL-2/mTRP12) by phorbol derivatives. J Biol Chem 2002, 277:13569-13577.

91. Klausen TK, Pagani A, Minassi A, Ech-Chahad A, Prenen J, Owsianik G, Hoffmann EK, Pedersen SF, Appendino G, Nilius B: Modulation of the transient receptor potential vanilloid channel TRPV4 by 4alpha-phorbol esters: a structure-activity study. J Med Chem 2009, 52:2933-2939.

92. Thorneloe KS, Sulpizio AC, Lin Z, Figueroa DJ, Clouse AK, McCafferty GP, Chendrimada TP, Lashinger ES, Gordon E, Evans L, Misajet BA, Demarini DJ, Nation JH, Casillas LN, Marquis RW, Votta BJ, Sheardown SA, Xu X, Brooks DP, Laping NJ, Westfall TD: N-((1S)-1-\{[4-((2S)-2-\{[(2,4-dichlorophenyl)sulfonyl] amino\}-3-hydroxypropa noyl)-1-piperazinyl]carbonyl\}-3-methylbutyl)-1benzothiophene-2-carboxamide (GSK1016790A), a novel and potent transient receptor potential vanilloid 4 channel agonist induces urinary bladder contraction and hyperactivity: Part I. J Pharmacol Exp Ther 2008, 326:432-442.

93. Kiselyov K, Patterson RL: The integrative function of TRPC channels. Front Biosci 2009, 14:45-58.

94. Zygmunt PM, Petersson J, Andersson DA, Chuang H, Sorgard M, Di Marzo V, Julius D, Hogestatt ED: Vanilloid receptors on sensory nerves mediate the vasodilator action of anandamide. Nature 1999, 400:452-457.

95. Watanabe H, Vriens J, Prenen J, Droogmans G, Voets T, Nilius B: Anandamide and arachidonic acid use epoxyeicosatrienoic acids to activate TRPV4 channels. Nature 2003, 424:434-438.

96. Grimm C, Kraft R, Schultz G, Harteneck C: Activation of the melastatinrelated cation channel TRPM3 by D-erythro-sphingosine [corrected]. Mol Pharmacol 2005, 67:798-805.

97. Kym PR, Kort ME, Hutchins CW: Analgesic potential of TRPV1 antagonists. Biochem Pharmacol 2009, 78:211-216.

98. Derry S, Lloyd R, Moore RA, McQuay HJ: Topical capsaicin for chronic neuropathic pain in adults. Cochrane Database Syst Rev 2009:CD007393.

99. Mukerji N, Damodaran TV, Winn MP: TRPC6 and FSGS: the latest TRP channelopathy. Biochim Biophys Acta 2007, 1772:859-868.

100. Sinkins WG, Goel M, Estacion M, Schilling WP: Association of immunophilins with mammalian TRPC channels. J Bio/ Chem 2004, 279:34521-34529.

101. Everaerts W, Zhen X, Ghosh D, Vriens J, Gevaert T, Gilbert JP, Hayward NJ, McNamara CR, Xue F, Moran MM, Strassmaier T, Uykal E, Owsianik G, Vennekens R, De Ridder D, Nilius B, Fanger CM, Voets T: Inhibition of the cation channel TRPV4 improves bladder function in mice and rats with cyclophosphamide-induced cystitis. Proc Natl Acad Sci U S A 2010, 107:19084-19089.

102. Perriere G, Gouy M: WWW-query: an on-line retrieval system for biological sequence banks. Biochimie 1996, 78:364-369.

103. Clapham DI, Nilius B, Owsianik G: Transient Receptor Potential Channels. IUPHAR database [http://www.iuphar-db.org/DATABASE/ FamilyMenuForward?familyld=78]

104. Montell C: TRP channels in Drosophila photoreceptor cells. J Physio/ 2005, 567:45-51.

105. Venkatachalam K, Montell C: TRP channels. Annu Rev Biochem 2007 76:387-417.

106. Christensen AP, Corey DP: TRP channels in mechanosensation: direct or indirect activation? Nat Rev Neurosci 2007, 8:510-521.

doi:10.1186/gb-2010-12-3-218

Cite this article as: Nilius B, Owsianik G: The transient receptor potential family of ion channels. Genome Biology 2011, 12:218. 